\title{
Tenurial Conflicts Within Protected Forest Management Unit (PFMU) of Tarakan, North Kalimantan
}

\author{
Erna Rositah ${ }^{1,2, *}$ Mustofa Agung Sardjono ${ }^{1}$ Marlon Ivanhoe Aipassa ${ }^{1}$ \\ Suyadi ${ }^{3}$ Ernita Obeth ${ }^{4}$
}

\author{
${ }^{1}$ Faculty of Forestry, Mulawarman University. Jl. Kuaro, Samarinda 75119, P.O. Box 1068, East Kalimantan, \\ Indonesia \\ ${ }^{2}$ Forest Management Department, Samarinda State of Agricultural Polytechnic, Jl. Sam Ratulangi Gunung Panjang, \\ Samarinda 75131, P.O. Box 192, East Kalimantan, Indonesia. \\ ${ }^{3}$ Faculty of Agriculture, Mulawarman University Jl. Pasir Balengkong, Gn. Kelua, Samarinda, East Kalimantan \\ 75117, Indonesia. \\ ${ }^{4}$ Plantation Management Department, Samarinda State of Agricultural Polytechnic, Jl. Samratulangi Gunung \\ Panjang, Samarinda 75131, P.O. Box 192, East Kalimantan, Indonesia. \\ *Corresponding author. Email: ernarositah7@gmail.com
}

\begin{abstract}
This research aims to discuss the forms, actors involved, causes, and alternative solutions in regards to tenurial conflicts occurring within the protected forest management unit of Tarakan. We used a qualitative approach using indepth interviews, observation, and taking field notes. Participants of the study were selected using purposive and snowball sampling. The conflicts are aroused when indigenous communities claim that the forests belong to them. Others include local entrepreneurs who encroach and occupy forestland for settlement, agriculture, and farming. Many cases showed that members of local communities buy and sell forest land. The leading causes of conflicts include unclear boundaries of forests, poor law enforcement, the dualism of forest authority, and ego sectoral of government agencies. To resolve the conflicts, we empowerment of communities through forestry partnership, law enforcement, strengthening of agencies both for the Protected Forest Management Unit (PFMU) of Tarakan and the Community to support the implementation of forestry partnership.
\end{abstract}

Keywords: Tenurial, Conflict, Local communities, Forestry partnership

\section{BACKGROUND}

Tenurial conflict is a classic issue that needs to be resolved until the present day. According to (1), tenurial refers not only to its definite meaning but also a guarantee of right. Since the forest is considered a public resource, therefore, forest tenurial-right involves the right to access, use, and ownership transfer. (2) stated that from January 1997 to June 2003, there had been 359 tenurial conflicts. Of $39 \%$ is occurring in Industrial Timber Estates (Hutan Tanaman Industri or $H T I$ ), $34 \%$ in conservation areas and protected forests, and $27 \%$ in Timber Estates (Hak Pengusahaan Hutan or $H P H)$ areas. About 157 conflicts regarding natural resources have been identified in 2011, of which 65 cases $(41 \%)$ occurred within forest areas. The number of cases is higher than in other sectors (3). Furthermore, (4) stated that the number of tenurial conflicts in the forestry sector is 72 cases in 2013 occurring over a total of 1.2 million hectares.

Protected Forest Management Unit (hereafter, PFMU) of Tarakan (KPHL Tarakan) initially oversees 4,623 hectares according to the Ministry of Forestry Decree Number: SK.738/Menhut-II/2009, and extend to 7,044 hectares according to the Ministry of Forestry Decree Number: SK. 942/Menhut-II/2013. The extension results in more tenurial conflicts involving various actors with different interests. Therefore, careful conflict analysis is needed to design appropriate conflict resolutions. 


\section{RESEARCH METHOD}

The research was conducted in 2017 at the Protected Forest Management Unit (PFMU) of Tarakan, North Kalimantan. We used purposive sampling to select respondents. The key informants were determined using the snowball-sampling. Primary key informants included the chief and staff of PFMU of Tarakan, elders of the indigenous Community (Tidung), the head of six villages surrounding PFMU, i.e., Juata Laut, Juata Kerikil, Kampung Satu/Skip, Kampung Enam, and Pantai Amal. Other respondents were representatives of the Public Works Office (Dinas Pekerjaan Umum); Food, Agriculture and Fishery Office (Dinas Pangan, Pertanian dan Perikanan), as well as people who live in the protected forest area.

\section{RESULT AND DISCUSSION}

\subsection{General Overview of KPHL Tarakan}

Non-Forest Use Area surrounds PFMU of Tarakan. PFMU of Tarakan shares its border with several urban villages in several different sub-districts. In the north, PFMU of Tarakan borders with two villages in North Tarakan Sub-district, i.e., Juata Kerikil and Juata Laut; two villages in East Tarakan Sub-district in the south, i.e. Pantai Amal and Kampung Enam; Kampung Satu/Skip in Central Tarakan Sub-district in the west and Karang Anyar Village of Sub-district West Tarakan in the west.

\subsection{Socio-Economic Condition in Tarakan}

Tarakan has an area of $250.80 \mathrm{~km}^{2}$ with a population of 244,185 (127,933 male and 116,252 female). Its population density of 974 people per $\mathrm{km}^{2}$ is far above the average population density of North Kalimantan Province which is only 8.83 people per $\mathrm{km}^{2}$. The high population growth rate cannot be separated from the fact that Tarakan lies in a strategic location. This strategic position is due to three main reasons. Firstly, the port and airport connecting North Kalimantan Province to other parts of Indonesia as well as neighbouring countries such as Malaysia and the Philippines are located in Tarakan. Secondly, Tarakan serves as the transit city for people, products, and services to be distributed to different parts of North Kalimantan Province. Thirdly, Tarakan drives the growth of other cities in North Kalimantan.

\subsection{Tenurial Conflict Mapping in PFMU of Tarakan}

Land ownership is a sensitive subject in Tarakan. Up to today, 22 conflict spots have been identified across FMR within the PFMU of Tarakan. Tenurial conflicts in the protected forest of Tarakan come in various forms.

\subsubsection{The Conflict Between PFMU of Tarakan and Indigenous Communities}

Intense claim from indigenous communities, mainly the Tidung community has been a source of the problem in the protected forest area. According to [5], the main issue is related to legal certainty. The forest administered by PFMU of Tarakan belongs to the government, yet the indigenous communities claim that it belongs to them.

The problem worsens as such a claim from Tidung Community occurs in other locations at the same time. The community takes shelter in the Association of Adat Besar Dayak Tidung Kalimantan Utara and the Association of Adat Tidung Ulun Pagun Tarakan. Lembaga Adat Besar Dayak Tidung Kalimantan Utara claims over approximately 410 ha in North RPH while Lembaga Adat Tidung Ulun Pagun Tarakan claims over 350 ha in South RPH. It was suspected that members of these communities sell the land for money. Association of Adat Besar Dayak Tidung hands over the forest area that it controls to the government who has to give some money for compensation. The fact that there are two associations of the same ethnicity with two different demands indicates that the claim is not in line with the real value of the Tidung.

\subsubsection{The Conflict Between PFMU of Tarakan and Illegal Users of Protected Forest}

Tarakan is located on a small island. The ability of its environment to support the livelihood of its people depends on the sustainability of its forests. On the other hand, its fast growth of population can be a threat to the forests as the demand for settlement increases. People start to encroach forests for settlement, agriculture, plantation, and farming. They have been a source of conflict between the government and local people.

According to [6], 510.5 ha forestland has been converted into a settlement area in four different locations. The first location is for permanent settlement area $(250 \mathrm{ha})$, the second is also for permanent settlement area (250 ha), the third is for semi-permanent settlement area (10 ha), and the fourth is non-permanent settlement area (0,5 ha). People have inhabited these locations before they are established as a protected forest area. Thus, it is not surprising to see permanent and semi-permanent houses along with public facilities like permanent roads, schools, and clinics on protected forestland. Moreover, people living outside the forestland area have utilized parts of the land to grow paddy, secondary crops, fruits, and eucalyptus.

\subsubsection{Conflict Within the Community}

Tenurial conflict is also marked with the forestland transaction. A land is a popular form of investment 
because its value increases over time. People have been selling and buying land illegally since they have no certificate over land. Generally, buyers only receive a receipt to prove that they have purchased the land. It leads to a complicated problem where two parties or more can claim ownership over the same piece of land. Thus, tenurial conflicts exist both between the community with the government (PFMU of Tarakan) and between members of the community.

\subsubsection{Conflict in the Construction of Public Infrastructure}

Another source of conflict arises from the fact that public infrastructures have been built within protected forest areas. These infrastructures include health facilities, education facilities, roads, and the city's reservoir that is known as Embung Binalatung by the locals. Data shows the total length of the road is 180 $\mathrm{km}$, of which over $50 \% \mathrm{~km}$ is paved with asphalt, and only $25 \%$ is a gravel road. It creates smooth traffic going in and out of the protected forest area and positively improves how the forest activities are managed and controlled. On the other hand, such development threatens the safety and conservation of the forest.

The presence of these public infrastructures implies that there was a large investment in the Protected Forest Management Unit (PFMU) of Tarakan. Therefore, the management of protected forest must be carried out in a way that does not collide with the conservation of natural resources of the forest especially now that according to [7], development of the urban area that increases the demand for settlement along with infrastructures (terminals, public cemeteries, and other public facilities) have driven more people towards the protected forests.

While some tenurial conflicts are still at the preconflict stage, the majority are already at the confrontation stage, leading to open confrontation. The latter case is dominated by conflicts between groups among the Tidung community who claims over pieces of forestland and between groups of community encroaching the forest.

\subsection{The Cause of Tenurial Conflicts}

It is crucial to identify the cause of a conflict before trying to resolve it. Tenurial conflicts in Tarakan are similar to those in other parts of Indonesia ([2] and [8]). There are six causes of conflicts in the PFMU of Tarakan. Firstly, rapid population growth in relatively limited space has driven people to encroach forests for income sources. Secondly, social jealousy and the history of indigenous people lead to land occupancy conflicts. Thirdly, the law is poorly enforced due to the lack of resources (human, financial, and facility) and poor coordination. Fourthly, the boundaries of protected forests are left unclear in some areas. Fifth, the usage of forestland is overlapping. And sixth, there is a dual authority between the administrative hierarchy and PFMU of Tarakan.

Decrees concerning the boundary and legitimation of forest areas are also contradictory. A decree issued by the Minister of Forest No. 79/Kpts-II/2001 on March 15th, 2001 on Forest and Water Territorial of East Kalimantan entails overlapping and discrepancy between the intended and actual use of the forest. Things went worse with the issued of Regional Regulation No. 4 in 2012 on Urban Land Use of Tarakan in which the width of the forest is altered by putting the Other Usage Area under PFMU of Tarakan. Some other regulations on forest areas in Tarakan have made it harder to establish the definitive boundary of PFMU of Tarakan [7].

Furthermore, the PFMU of Tarakan faces internal problems due to the lack of human resources in terms of quality and quantity. This condition makes it difficult for the PFMU of Tarakan to communicate and coordinate forest resources management policies to the stakeholders. Until today, there are only six forest rangers or Indonesian Forest Police. As a result of Constitution No. 23 on Local Governance implementation, many forestry civil servants in district offices are transferred to provincial offices.

\subsection{Conflict Resolution Model}

Three alternative resolutions to the tenurial conflicts are as follow:

\subsubsection{Partnership Scheme}

The partnership between PFMU of Tarakan and the Community not only will improve the way the community utilizes forestland but also aid in protecting the forest. [9] stated that partnership serves as a community empowerment program that will help farmers develop a sense of belonging in the way they utilize land forests for their welfare. A mutualistic partnership is built by balancing the economic benefit of forests and the conservation of biodiversity and hydrological function of the forest.

Nevertheless, the community is not to think that such partnership allows it to further use forestland for farming. [8] confirmed this when they said that a partnership scheme is not permitted for any party, including local entrepreneurs, to use the land within the protected forest for business. According to [10], the Ministerial Decree No.39/Menut-II/2013 is unlikely to satisfy all parties, specifically the community; however, such a scheme provides legality for the community to utilize the forest 
from the government's perspective and legitimacy of forest area from the community's perspective.

\subsubsection{Law Enforcement}

Law enforcement emphasizes the mechanism to ensure law compliance in protecting the forest, land, ecosystem, and the community whose lives depend on forest resources. The biggest challenge in law enforcement is the inadequate capacity of the resources. The inadequate capacity is caused by the lack of training and experience for the staff, the staffs' lack of understanding of the law, and the lack of financial support.

\subsubsection{Strengthening of Agency}

Strengthening of government agencies, specifically PFMU of Tarakan, needs to be done in terms of quality and quantity. Coaching, training, and education will improve their skills in communication, negotiation, policy implementation, professionalism, and the authority of forest rangers. With regards to the community, agency strengthening will support the implementation of partnership schemes.

\section{CONCLUSION}

Tenurial conflicts within the protected forest of Tarakan are marked with indigenous forest claim, land occupancy, forest encroachment for settlement, agriculture and farming, forestland transactions, and construction for public facilities within the protected forest area. Tenurial conflict involves the PFMU of Tarakan, indigenous communities, local entrepreneurs, and government agencies. The reasons behind these conflicts are forests' unclear boundaries, poor law enforcement, the dualism of forest authority, and the sectorial ego of government agencies. Alternative resolutions to tenurial conflicts include community empowerment through partnership, improved law enforcement, and agency strengthening both within PFMU of Tarakan and the Community to support the implementation of the partnership.

\section{ACKNOWLEDGMENT}

This research is funded with the Kaltim Cemerlang Scholarship from the Government of East Kalimantan Province. The authors would like to thank the PFMU of Tarakan, the communities in Tarakan, especially the elders of the Tidung community and other communities within the protected forest area for the excellent discussion and valuable information.

\section{REFERENCES}

[1] A.M. Larson, Hak Tenurial dan Akses Ke Hutan: Manual Pelatihan untuk Penelitian, Center for International Forestry Research (CIFOR), Bogor, 2013

[2] Y.C. Wulan, Y. Yasmi, C. Purba, E. Wollenberg, Analisa Konflik: Sektor Kehutanan di Indonesia 1997-2003, CIFOR, Bogor, 2004

[3] D.S. Nurmala, Andiko, Warta Tenure, Edisi ke-10, ISSN-1978-1865, 2012

[4] I. Hakim, L.R. Wibowo, Jalan Terjal Reforma Agraria di Sektor Kehutanan, Pusat Penelitian dan Pengembangan Perubahan Iklim dan Kebijakan, Bogor, 2013

[5] M. Syukur (Ed), Resolusi Konflik di KPH (Pembelajaran dari KPH Register 47 \& Rinjani Barat). Working Group Tenure, Bogor, 2012

[6] UPTD KPHL Tarakan, Rencana Pengelolaan Hutan Jangka Panjang (RPH-JP) Kota Tarakan Kalimantan Utara Tahun 2015-2024, Dinas Kehutanan, Pertambangan dan Energi KPHL Tarakan, 2014

[7] E.S. Slamet, S. Sujatmoko, Kajian Konflik Pengelolaan KHDTK Hutan Penelitian HambalaSumba Timur. Jurnal Analisis Kebijakan Kehutanan Vol. 5 No. 3, 2008, pp. 165 - 178

[8] I. Arif, K. Mairi, S. Ekawati, Analisis Konflik Tenurial di Kesatuan Pengelolaan Hutan Produksi (KPHP) Model Poigar, Jurnal Wasian Vol.3 No.2, 2016, pp. 79-90

[9] N. Laila, K. Murtilaksono, B. Nugroho, Institutional upstream-downstream partnership for Cidanau watershed supply, Banten Province, Journal Research Sosial dan Ekonomi Kehutanan, 11(2), 2014, pp. 137-152.

[10] Gamin, Resolusi Konflik dalam Pengelolaan Hutan Untuk Mendukung Implementasi REDD+, Sekolah Pascasarjana Institut Pertanian Bogor, 2014 